\title{
Ruminal biohydrogenation and abomasal flow of fatty acids in lactating cows: Oilseed provides ruminal protection for fatty acids
}

\author{
Rafael V. Barletta ${ }^{a}$, Jefferson R. Gandra ${ }^{a}$, Vitor P. Bettero ${ }^{b}$, Cybelle E. Araújo ${ }^{a}$, \\ Tiago A. Del Valle ${ }^{a}$, Gustavo F.de Almeida ${ }^{a}$, Elmeson Ferreira de Jesus ${ }^{b}$, \\ Rodolfo D. Mingoti ${ }^{a}$, Bruna C. Benevento ${ }^{a}$, José E. de Freitas Júnior ${ }^{a}$, Francisco \\ P. Rennó ${ }^{\mathrm{a}, *, 1}$ \\ a Department of Animal Nutrition and Production, University of Sao Paulo, Pirassununga, Brazil \\ b Department of Animal Science, UNESP-Universidade Estadual Paulista “Júlio de Mesquita Filho", Jaboticabal, Brazil
}

\section{A R T I C L E I N F O}

\section{Article history:}

Received 4 February 2016

Received in revised form 15 June 2016

Accepted 16 June 2016

\section{Keywords:}

Calcium salts

Linoleic acid

Lipids

Passage rate

Ruminal digestibility

Soybean oil

\begin{abstract}
A B S T R A C T
Fat sources, besides the energy-rich content, have featured beneficial effects on dairy cow production, reproduction and health. This work aimed to study the biohydrogenation process and fatty acid abomasal flow in lactating dairy cows fed different fat sources. Eight rumen and abomasum cannulated cows ( $188 \pm 27.3$ days in milk, $18.9 \pm 3.24 \mathrm{~kg}$ of milk yield, and $572 \pm 59.6 \mathrm{~kg}$ of body weight) were used in a $4 \times 4$ Latin square design. Control (CON) diet without fat source, soybean oil (SO), raw soybean grain (SG) and calcium salts of unsaturated fatty acids (CS) were evaluated. Fat sources decreased dry matter (DM), crude protein and neutral detergent fiber (NDF) intake and increased ether extract (EE) intake and ruminal $\mathrm{pH}(\mathrm{P}<0.05)$. Acetate to propionate ratio was lower in animals fed diets with fat $(P<0.05)$. Diets had no effect on microbial protein synthesis, and energy and nitrogen balances. NDF digestibility and DM passage rate were lower in animals fed diets with fat sources $(\mathrm{P}<0.05)$, while protected sources $(\mathrm{SG}$ and $\mathrm{CS})$ tended to increase ruminal fiber digestibility $(\mathrm{P}=0.092)$ in relation to SO diet. Intake and abomasal flow of FA were higher $(\mathrm{P}<0.05)$ for animals supplemented with fat sources than those fed CON. Protected sources (SG and CS) promoted greater abomasal flow of linoleic acid (C18:2) and lower biohydrogenation rate compared to the SO diet. Fat sources increased unsaturated milk fatty acids and serum cholesterol concentration while protected sources (SG and CS) increased milk C18:2 cis concentration $(\mathrm{P}<0.05)$. Fat sources improved ruminal fermentation without compromise nutrients digestion and increasing fatty acids abomasal flow and milk concentration. Raw soybean grain had higher ruminal biohydrogenation protection than calcium salts.
\end{abstract}

(c) 2016 Elsevier B.V. All rights reserved.

Abbreviations: aADF, acid detergent fiber; aNDF, neutral detergent fiber; A:P, acetate to propionate ratio; CLA, conjugated linoleic acid; CON, control; $\mathrm{CP}$, crude protein; CS, calcium salts of fatty acids; DC, digestibility coefficient; DM, dry matter; DMI, dry matter intake; EE, ether extract; FA, fatty acids;

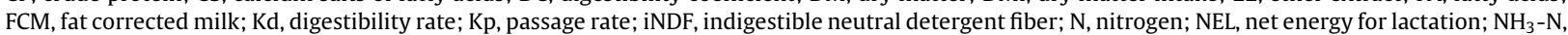
ammonia nitrogen; PUFA, polyunsaturated fatty acid; SEM, standard error of the mean; SCFA, short-chain fatty acids; SG, raw soybean grain; SO, soybean oil; tdNDF, truly digestible NDF.

* Corresponding author.

E-mail address: francisco.renno@usp.br (F.P. Rennó).

1 Bursar 1-C of National Council of Scientific and Technologic Development. 


\section{Introduction}

Dairy farming productivity worldwide heavily relies on intensive practices that include providing animals with ideal ratios of available grains, roughage, and commercial feeds. Fat content and composition represent key aspects of dairy cow feeds. In this sense, fat sources have been extensively studied, not only as a means of maintaining energy balance with low heat increment for dairy cows, but also as metabolic modulators and animal health promoters (Onetti and Grummer, 2004; Jenkins et al., 2008). Altering the fatty acid (FA) supply to dairy cows affects immune function (Silvestre et al., 2011), nutrient flow (Harvatine and Allen, 2006), animal performance and, ultimately, the composition and quality of dairy products (Mansbridge and Blake, 1997).

Ruminants absorb lipids mostly in the duodenum. The quality and degree of fat absorption by duodenum depends on the dietary FA composition and ruminal metabolism (Harvatine and Allen, 2006). In turn, this process varies with the amount of polyunsaturated fatty acids (PUFA) reaching the rumen. High PUFA contents affect ruminal microorganisms reducing fiber digestibility (Eastridge and Firkins, 1991). As a defense mechanism, these microorganisms bio-hydrogenate PUFA in a process that depends on $\mathrm{pH}$ (VanNevel and Demeyer, 1996) and on the amount and profile of fat (Beam et al., 2000).

Producers should attempt to optimize ruminal metabolic processes, fatty acids absorption in the duodenum, and productivity following breed guidelines and providing animals with an appropriate amount and quality of dietary FA. Few studies focused on the extent in which dietary FA are protected and reach duodenum for absorption. However, it is well established that the degree of FA protection will heavily depends on the source. For example, oilseeds (Chilliard et al., 2000) and calcium salts of FA (Jenkins and Bridges, 2007) provide greater protection to FA against rumen biohydrogenation than vegetable oils.

Given the importance of absorbed FA to animal health and performance, specifically regarding dairy cows and being linoleic acid the major unsaturated FA in conventional fat sources, we evaluated the effects of different fat sources, rich in linoleic acid on nutrients intake and digestibility, ruminal kinetics, biohydrogenation, and abomasal flow of FA. We hypothesized that ruminal protection (mechanic or chemical) inhibits ruminal biohydrogenation, increases unsaturated FA abomasal flow and milk secretion, without affecting performance and ruminal kinetics and fermentation of lactating dairy cows.

\section{Material and methods}

The Ethics Committee of the School of Veterinary Medicine and Animal Science of the University of Sao Paulo approved the experimental procedures approval number 1603/2009.

\subsection{Animals, experimental design and diets}

The study used eight Holstein cows cannulated in rumen and abomasum, which averaged $188 \pm 27.3$ days in milk, $572 \pm 59.6 \mathrm{~kg}$ of body weight, and $18.9 \pm 3.24 \mathrm{~kg} / \mathrm{d}$ of milk yield at the beginning of the trial. Animals were housed in individual pens, with $17.5 \mathrm{~m}^{2}$ of area, sand beds and forced ventilation and were mechanically milked twice daily. The animals were allocated into two Latin squares to receive one of four experimental diets (Table 1) formulated according to the NRC (2001) recommendations, as follows: CON: control diet with no fat source; SO: soybean oil, with $30 \mathrm{~g} / \mathrm{kg}$ of soybean oil; SG: soybean grain diet, with $160 \mathrm{~g} / \mathrm{kg}$ of whole raw soybean grain; and CS: calcium salts, with $30 \mathrm{~g} / \mathrm{kg}$ of calcium salts of fatty acids (Megalac $E^{\circledR}$, Church \& Dwight Company and distributed by Química Geral do Nordeste, Nova Ponte, Brazil). Each experimental period lasted for 21 days, consisting of 14 days for adaptation to diets and seven days for sampling.

\subsection{Data and sample collection}

\subsubsection{Nutrients intake and apparent digestibility}

Cows were fed a total mixed ration twice daily, at 06:00 and 13:00, according to the amount of orts from the previous day to maintain a percentage of refusal between 50 and $100 \mathrm{~g} / \mathrm{kg}$ of the feed offered. Samples of feed and refusals were collected throughout the sampling period and frozen until chemical analyses. Fecal samples ( $500 \mathrm{~g})$ were collected every nine hours on days 15,16 , and 17 of the experimental period, forming a composite sample.

Feed, refusal, and fecal samples were analyzed for dry matter (method 930.15; AOAC, 2000), crude protein (N $\times 6.25$; method 984.13; AOAC, 2000), ether extract (method 920.39; AOAC, 2000), acid-detergent fiber and lignin (ADF-ADF and Lignin (sa), method 973.18; AOAC, 2000), ash (method 942.05; AOAC, 2000), neutral-detergent fiber and neutral-detergent fiber corrected for ash and protein (aNDF-NDF), and using $\alpha$-amylase without addition of sodium sulfite (VanSoest et al., 1991).

Feed samples were evaluated for neutral-detergent insoluble crude protein and acid-detergent insoluble crude protein, according to the methods described in the NRC (2001) for assessing net energy of lactation ( $\mathrm{NEL}_{3 \mathrm{x}}$ ).

Fecal excretion was estimated using chromic oxide as marker. From day 9-17 of each experimental period, $15 \mathrm{~g} / \mathrm{d}$ of chromium oxide were inserted in the rumen through the cannula. Phosphoric acid was used in the fecal sample digestion 
Table 1

Experimental diets composition and fatty acid profile.

\begin{tabular}{|c|c|c|c|c|}
\hline Item & $\mathrm{CON}^{\mathrm{a}}$ & $\mathrm{SO}^{\mathrm{b}}$ & $\mathrm{SG}^{\mathrm{c}}$ & $\mathrm{CS}^{\mathrm{d}}$ \\
\hline \multicolumn{5}{|l|}{ Ingredients, $\mathrm{g} / \mathrm{kg}$} \\
\hline Corn silage & 650 & 650 & 650 & 650 \\
\hline Ground corn & 210 & 180 & 139 & 180 \\
\hline Soybean meal & 107 & 106 & 20.0 & 106 \\
\hline Soybean oil & - & 30.2 & - & - \\
\hline Raw soybean grain & - & - & 160 & - \\
\hline Calcium salts of fatty acids & - & - & - & 30.2 \\
\hline Urea & 8.0 & 9.5 & 4.0 & 8.0 \\
\hline Ammonium sulfate & 2.0 & 2.0 & 1.0 & 2.0 \\
\hline Magnesium oxide & 1.6 & 1.6 & 1.6 & 1.6 \\
\hline Dicalcium phosphate & 6.3 & 6.3 & 6.2 & 6.3 \\
\hline Limestone & 7.4 & 7.4 & 8.9 & - \\
\hline Minerals ${ }^{e}$ & 2.1 & 2.1 & 2.1 & 2.1 \\
\hline \multicolumn{5}{|l|}{ Nutrient composition } \\
\hline Dry matter, $\mathrm{g} / \mathrm{kg}$ & 575 & 577 & 582 & 557 \\
\hline Neutral detergent fiber, $\mathrm{g} / \mathrm{kg}$ & 364 & 360 & 346 & 360 \\
\hline Crude protein, $\mathrm{g} / \mathrm{kg}$ & 141 & 141 & 139 & 141 \\
\hline Ash, $\mathrm{g} / \mathrm{kg}$ & 80.3 & 87.4 & 82.9 & 87.4 \\
\hline Ether extract, g/kg & 27.3 & 53.4 & 56.6 & 53.4 \\
\hline $\mathrm{NE}_{\mathrm{L} 3} \times{ }^{\mathrm{f}} \mathrm{MJ} / \mathrm{kg}$ & 7.87 & 8.37 & 8.49 & 8.28 \\
\hline \multicolumn{5}{|l|}{ Fatty acid, $\mathrm{g} / \mathrm{kg}$ of FA } \\
\hline C14:0 & 3.1 & 3.3 & 2.7 & 3.1 \\
\hline C16:0 & 113 & 116 & 124 & 113 \\
\hline C18:0 & 32.3 & 32.1 & 33.6 & 32.1 \\
\hline cis C18: 1 & 228 & 224 & 219 & 225 \\
\hline C18:2 & 504 & 503 & 507 & 501 \\
\hline C18:3 & 55.8 & 54.2 & 56.9 & 56.3 \\
\hline Others & 11.7 & 5.4 & 3.4 & 4.1 \\
\hline Total unsaturated fatty acids & 799 & 787 & 786 & 786 \\
\hline
\end{tabular}

a Control (CON).

b Soybean oil (SO).

c Soybean grain (SG).

d Calcium salts of fatty acids (CS) (Megalac-E ${ }^{\circledR}$ ).

e Each kg contains: $125 \mathrm{mg}$ of Co, $5625 \mathrm{mg}$ of Cu, $9 \mathrm{mg}$ of S, $312 \mathrm{mg}$ of I, $5000 \mathrm{mg}$ of Fe, 18,125 mg of Mn, $144 \mathrm{mg}$ of Se, $23,750 \mathrm{mg}$ of Zn, 2000 IU of Vitamin A, 500 IU of Vitamin D, 12,500 IU of Vitamin E.

f Estimated according to NRC (2001): $\mathrm{NE}_{\mathrm{L3x}}(\mathrm{MJ} / \mathrm{kg} \mathrm{MS})=\left[0.245 * \mathrm{TDN}_{1 \mathrm{x}}(\mathrm{g} / \mathrm{kg})-0.12\right] * 4.184$, were total digestible nutrients(TDN) were estimated as: $\mathrm{TDN}_{1 \mathrm{X}}(\mathrm{g} / \mathrm{kg})=\operatorname{tdNFC}(\mathrm{g} / \mathrm{kg})+\operatorname{tdCP}(\mathrm{g} / \mathrm{kg})+(\operatorname{tdFA}(\mathrm{g} / \mathrm{kg}) * 2.25)+\operatorname{tdNDF}(\mathrm{g} / \mathrm{kg})$; where tdNFC, tdCP, tdFA and tdNDF were the truly digestible fraction of non fiber carbohydrate, crude protein, fatty acids and neutral detergent fiber, respectively.

(Williams et al., 1962) and readings were made in a spectrophotometer (Biochrom Asys Expert, Holliston, MA, United States). Fecal excretion and apparent digestibility coefficient (DC) were estimated according the following equations:

$$
\begin{aligned}
& \text { Fecal excretion }\left(\frac{\mathrm{kg}}{\text { day }}\right)=\frac{\text { Cromiumoxidedoseddaily }\left(\frac{\mathrm{g}}{\text { day }}\right)}{\text { Cromium oxide fecal concentration }\left(\frac{\mathrm{g}}{\mathrm{kg}}\right)} \\
& \mathrm{DC}\left(\frac{\mathrm{g}}{\mathrm{g}}\right)=\frac{\operatorname{Intake}(\mathrm{kg})-\text { Fecal excretion }(\mathrm{kg})}{\text { Intake }(\mathrm{kg})}
\end{aligned}
$$

\subsubsection{Ruminal fermentation}

For ruminal fermentation evaluation, liquid was collected on day 17 of each experimental period at zero, 2, 4, 6, 8, 10, and $12 \mathrm{~h}$ after the morning feeding. The rumen $\mathrm{pH}$ value was recorded immediately after collection with a digital $\mathrm{pH}$ meter (MB-10, Marte Científica, Santa Rita do Sapucaí, Brazil). The concentrations of short chain fatty acids (SCFA) in the rumen liquid were measured as described by Shen et al. (2004), and the $\mathrm{NH}_{3}-\mathrm{N}$ content was analyzed using phenol-hypochlorite method (Broderick and Kang, 1980).

\subsubsection{Ruminal kinetics}

Ruminal (1000 g) and abomasal (1000 g) samples were collected every nine hours on days 15 , 16 , and 17 of each experimental period, creating a composite sample representative of a 24-h cycle. Ruminal samples were separated with an 1 mm pore cheesecloth into liquid and solid content and after ground were reconstituted at original DM ratio (Faichney, 1975).

Rumen contents were manually evacuated through ruminal cannula 12:30 (4.5 h after feeding) on the 20th day of each period and 5:30 (2.5 h before feeding) on day 21 of each period (Harvatine and Allen, 2006). Feed, refused feed, ruminal, and abomasal samples were packed in bags of non-woven tissue $\left(100 \mathrm{~g} / \mathrm{m}^{2}\right)$ and incubated for $288 \mathrm{~h}$ in the rumen of two 
Holstein cows (Casali et al., 2008). Residues were analyzed for NDF (VanSoest et al., 1991) to assess the indigestible neutral detergent fiber (iNDF), which was used as internal marker.

Rumen turnover rate was calculated as iNDF intake and iNDF rumen content ratio. According to a two-compartment model for cellulose digestion (Waldo et al., 1972), ruminal passage rate $\left(k_{p}\right)$ of iNDF was calculated dividing the size of the rumen compartment by iNDF intake. Ruminal digestion rate $\left(\mathrm{k}_{\mathrm{d}}\right)$ of NDF was calculated as the difference between NDF clearance and passage rate (Allen and Mertens, 1988). The NDF ruminal apparent digestibility was assessed as: $k_{d} /\left(k_{d}+k_{p}\right)$. Truly digestible NDF (tdNDF) were calculated from the difference between NDF and iNDF (NRC, 2001), tdNDF ruminal digestion were estimated similarly to NDF.

Ruminal fluid turnover was estimated using a 4000 molecular weight Polyethylene glycol (PEG) as marker. Before the morning feeding, on day 18 of each experimental period, $100 \mathrm{~g}$ of PEG (Synth, Diadema, Brazil) were diluted in $400 \mathrm{~mL}$ of water and placed in the rumen. Samples were performed 0, 1, 2, 4, 8 and $24 \mathrm{~h}$ after infusion. PEG concentration were analyzed according to the Hyden (1955) methodology. Liquid passage rate were obtained by linear natural logarithmic regression in function of time.

\subsubsection{FA flow and biohydrogenation rate}

Feed and refusals, ruminal and abomasal content samples were ground using a Walley mill $5 \mathrm{~mm}$ sieve, liquid $\mathrm{N}$ at $-192^{\circ} \mathrm{C}$, to prevent oxidation of FA (Harvatine and Allen, 2006). Lipid extraction was performed according to the method proposed by Folch et al. (1957) and methylation performed according to Kramer et al. (1997). Fatty acids were quantified by gas chromatography (GC Shimatzu 2010, São Paulo, Brazil) using SP-2560 capillary column (Supelco, Bellefonte, PA).

The biohydrogenation rates were calculated by the Jenkins and Bridges (2007) model, using the following equation:

$$
B R P U F A=\left(P U F A_{a f}-P^{\prime} U F A_{i}\right) / P_{U F A}
$$

where BRPUFA: biohydrogenation rate of polyunsaturated fatty acid; $P U F A_{a f}$ : polyunsaturated fatty acid abomasal flow; and $P U F A_{i}$ : polyunsaturated fatty acid intake.

\subsubsection{Milk yield and composition}

Cows were mechanically milked twice a day, at 06:30 and at 15:30. Milk yield was recorded at each milking on day 14th to 21th, and samples were collected at 16th to 21th day and analyzed for crude protein, fat and lactose, using ultrasonic milk analyzer MCC (Milcotronic Company, Nova Zagora, 8900, Bulgaria). Milk yield was corrected for $35 \mathrm{~g} / \mathrm{kg}$ of fat (FCM), according Sklan et al. (1992).

Milk samples used for evaluating fatty acids profile were centrifuged at $17.800 \mathrm{~g}$ for $30 \mathrm{~min}$ at $4{ }^{\circ} \mathrm{C}$ and next for $19.300 \times \mathrm{g}$ for $20 \mathrm{~min}$ at $4{ }^{\circ} \mathrm{C}$, according to Feng et al. (2004). The separated fat $(0.300-0.400 \mathrm{~g})$ was methylated and the methyl esters were formed according to (Kramer et al., 1997). Two internal C18:0 and C19:0 FA standards were used for correcting losses during the process of methylation.

The fatty acids were quantified by chromatography gas (Shimadzu GC 2010 with automatic injection) using capillary column SP-2560 ( $100 \mathrm{~m} \times 0.25 \mathrm{~mm}$ i.d. with $0.02 \mathrm{~mm}$ of film thickness, Supelco, Bellefonte, PA, USA). The initial temperature was $70^{\circ} \mathrm{C}$ for four minutes $\left(13^{\circ} \mathrm{C} /\right.$ minute) until it reached $175^{\circ} \mathrm{C}$, maintaining for $27 \mathrm{~min}$. Afterward, a new increase of $4^{\circ} \mathrm{C}$ /minute was initiated until $215^{\circ} \mathrm{C}$, maintaining for $31 \mathrm{~min}$. Hydrogen $\left(\mathrm{H}_{2}\right)$ was used as carrier gas with flux of $40 \mathrm{~cm} / \mathrm{s}$. During the process of identification four standards were used: standard C4-C24 FA (Supelco ${ }^{\circledR}$ TM 37), vaccenic acid C18:1 trans-11 (V038-1G, Sigma ${ }^{\circledR}$ ), CLA C18:2 trans-10, cis-12 (UC-61 M 100 MG), and CLA C18:2 cis-9, trans-11 (UC-60 M 100 MG), (NU-CHEK-PREP USA ${ }^{\circledR}$ ) for identification of fatty acids that are formed during the biohydrogenation.

\subsubsection{Nitrogen balance and microbial protein synthesis}

The daily urinary volume was estimated from the concentration of creatinine $(\mathrm{g} / \mathrm{L})$ in spot samples obtained on the 16 th day of each experimental period, four hours after the morning feeding. The creatinine concentrations were analyzed with a biochemical colorimetric kit (kinetic creatinine: cat. no. K-067, Bioclin, Belo Horizonte, Brazil) in a semi-automatic spectrophotometer (SBA 200, CELM, São Caetano do Sul, Brazil), and a daily creatinine excretion rate of $0.024 \mathrm{~g} / \mathrm{kg}$ of body weight was assumed (Chizzotti et al., 2008). The total excretion of uric acid (uric acid stable liquid: cat. no. K-052, Bioclin, Belo Horizonte, Brazil; determined in a semi-automatic spectrophotometer SBA 200, CELM, São Caetano do Sul, Brazil) and allantoin in urine and milk (Fujihara and Yamaguchi, 1978) were considered as the total excretion of purine derivatives. Microbial protein synthesis was estimated from these concentrations in accordance with the Chen and Gomes (1992) method. Estimation of energy and protein balance was performed according to NRC (2001) equations.

\subsubsection{Serum glucose and cholesterol}

Blood samples were collected on the 19th day of each experimental period by puncture of a coccygeal vein or artery, before the morning feeding. The samples were centrifuged at $800 \mathrm{~g}$ for $10 \mathrm{~min}$, and the serum was collected and stored at $-20^{\circ} \mathrm{C}$. The analyses were performed with commercially available colorimetric kits (glucose: cat. no. K-082; total cholesterol: cat. no. K-083; Bioclin ${ }^{\circledR}$, Belo Horizonte, Brazil). The readings were determined with a semi-automatic spectrophotometer (SBA 200, CELM, São Caetano do Sul, Brazil). 
Table 2

Nutrient intake and total apparent digestibility of cows fed different fat sources.

\begin{tabular}{|c|c|c|c|c|c|c|c|c|}
\hline \multirow[t]{2}{*}{ Item } & \multicolumn{4}{|l|}{ Diet $^{\mathrm{a}}$} & \multirow[t]{2}{*}{$\mathrm{SEM}^{\mathrm{b}}$} & \multicolumn{3}{|l|}{$P^{c}$} \\
\hline & CON & SO & SG & CS & & $\mathrm{C} 1$ & $\mathrm{C} 2$ & C3 \\
\hline \multicolumn{9}{|l|}{ Intake } \\
\hline Dry matter, kg/d & 21.9 & 19.5 & 20.0 & 19.5 & 0.80 & 0.032 & 0.822 & 0.662 \\
\hline $\mathrm{NDF}^{\mathrm{d}}, \mathrm{kg} / \mathrm{d}$ & 7.91 & 6.95 & 7.31 & 6.88 & 0.31 & 0.044 & 0.739 & 0.394 \\
\hline Crude protein, kg/d & 2.76 & 2.45 & 2.43 & 2.54 & 0.09 & 0.019 & 0.780 & 0.441 \\
\hline Ether extract, kg/d & 0.61 & 1.03 & 1.00 & 1.09 & 0.05 & 0.001 & 0.713 & 0.166 \\
\hline $\begin{array}{l}\mathrm{NE}_{\mathrm{L} 3} \times{ }^{\mathrm{e}}, \mathrm{MJ} / \mathrm{d} \\
\text { Apparent digestibilit }\end{array}$ & 172 & 164 & 170 & 162 & 5.98 & 0.343 & 0.629 & 0.193 \\
\hline Dry matter & 0.692 & 0.651 & 0.641 & 0.661 & 0.015 & 0.071 & 0.740 & 0.520 \\
\hline Crude protein & 0.798 & 0.776 & 0.759 & 0.771 & 0.015 & 0.111 & 0.543 & 0.443 \\
\hline Ether extract & 0.922 & 0.950 & 0.938 & 0.945 & 0.005 & 0.017 & 0.294 & 0.641 \\
\hline $\mathrm{NDF}^{\mathrm{d}}$ & 0.568 & 0.526 & 0.538 & 0.529 & 0.009 & 0.052 & 0.504 & 0.108 \\
\hline
\end{tabular}

a Control (CON); soybean oil (SO); soybean grain (SG); calcium salts of fatty acids (CS) (Megalac-E $\mathrm{E}^{\circledR}$ ).

b Standard error of mean.

c Probability: C1 = CON vs fat sources (SO. SG. and CS); C2 = SO vs SG and CS; C3 = SG vs CS.

d NDF: Neutral detergent fiber.

e Estimated according to $\mathrm{NRC}(2001)$ : $\mathrm{NE}_{\mathrm{L} 3 \mathrm{x}}(\mathrm{MJ} / \mathrm{kg} \mathrm{MS})=\left[0.245^{*} \mathrm{TDN}_{1 \mathrm{x}}(\mathrm{g} / \mathrm{kg})-0.12\right] * 4.184$, were total digestible nutrients(TDN) were estimated as: $\mathrm{TDN}_{1 \mathrm{X}}(\mathrm{g} / \mathrm{kg})=\operatorname{tdNFC}(\mathrm{g} / \mathrm{kg})+\operatorname{tdCP}(\mathrm{g} / \mathrm{kg})+(\mathrm{tdFA}(\mathrm{g} / \mathrm{kg}) * 2.25)+\operatorname{tdNDF}(\mathrm{g} / \mathrm{kg})$; where tdNFC, tdCP, tdFA and tdNDF were the truly digestible fraction of non fiber carbohydrate, crude protein, fatty acids and neutral detergent fiber, respectively.
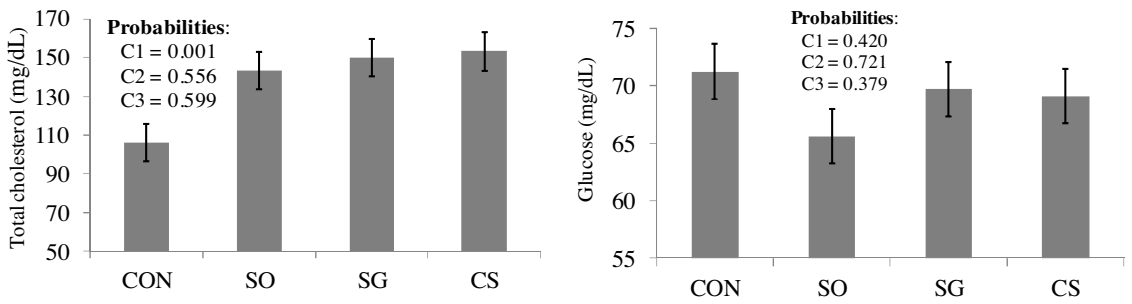

Fig. 1. Serum total cholesterol and glucose concentrations in cows fed different fat sources.

Mean \pm standard error of the mean. Control $(\mathrm{CON})$; soybean oil $(\mathrm{SO})$; soybean grain $(\mathrm{SG})$; calcium salts of fatty acids $(\mathrm{CS})\left(\mathrm{Megalac}-\mathrm{E}^{\circledR}\right)$. Probability: $\mathrm{C} 1=\mathrm{CON}$ vs fat sources (SO, SG, and CS); C2 = SO vs protected sources (SG and CS); C3 = SG vs CS.

\subsection{Statistical analyses}

Data were analyzed using PROC MIXED (Statistical Analysis System for Windows 9.0, SAS Institute Inc., Cary, USA), according to the following model:

$$
Y_{i j k l}=m+D_{i}+P_{j}+S_{k}+a_{l}\left(s_{\mathrm{k}}\right)+e_{i j k l}
$$

where: $Y_{i j k l m}$ was the observed value in the animal $l$, from $k$ square, in the $j^{\text {th }}$ period, which received the $i^{\text {th }}$ experimental diet; $\mu$ overall mean; $D_{i}$ was the fixed effect of diet; $P_{j}$ was the fixed effect of experimental period; $S_{k}$ was the fixed effect of the Latin square; $a_{l}\left(s_{k}\right)$ was the random effect of animal within Latin square; $e_{i j k l}$ was the random residual error.

Diets effect were studied in three orthogonal contrasts: C1: fat source effect (CON vs SO + SG + CS); C2: protected fat source effect (SO vs SG + CS); C3: protection type effect (SG vs CS). Degrees of freedom correction was made according to Kenward and Roger (1997). Means shown were adjusted by LSMEANS function.

The ruminal fermentation variables $\left(\mathrm{pH}, \mathrm{NH}_{3}-\mathrm{N}\right.$, acetate, propionate, butyrate, and total SCFA) were analyzed as repeated measures in PROC MIXED of SAS 9.0, considering in the statistical model the effects of animal, period, and experimental diet, beyond the effects of time with their interactions with the other effects mentioned above. Akakike criterion was used for choosing covariance structure. Differences were considered significant at the 0.05 level. Trends were considered at $\mathrm{P}<0.10$.

\section{Results}

\subsection{Feed intake and digestibility}

Animals fed with fat source diets had lower DM intake in relation to those fed control diet $(\mathrm{P}<0.05$; Table 2). Similarly, animals fed fat sources had lower CP and NDF intake and higher EE intake than those fed CON $(\mathrm{P}<0.05)$. Then, the observed decrease in DM and nutrient intake was directly related to the higher energy density of fat source diets (Table 1).

The experimental diets had no effect on net energy intake, DM and CP apparent digestibility and serum glucose concentration (Fig. 1). Although, fat sources increased ether extract digestibility and serum cholesterol concentration $(\mathrm{P}<0.05)$ and tended to decrease NDF $(\mathrm{P}=0.052)$ and dry matter $(\mathrm{P}=0.071)$ apparent digestibility. 
Table 3

Ruminal fermentation of dairy cows fed different fat sources.

\begin{tabular}{|c|c|c|c|c|c|c|c|c|c|c|}
\hline \multirow[t]{2}{*}{ Item } & \multicolumn{4}{|l|}{ Diet $^{\mathrm{a}}$} & \multirow[t]{2}{*}{ SEM $^{\mathrm{b}}$} & \multicolumn{5}{|l|}{$P^{c}$} \\
\hline & $\mathrm{CON}$ & SO & SG & $\mathrm{CS}$ & & Time & D*T I & $\mathrm{C} 1$ & $\mathrm{C} 2$ & $\mathrm{C} 3$ \\
\hline $\mathrm{pH}$ & 6.01 & 6.03 & 5.97 & 6.28 & 0.07 & $<0.001$ & 0.281 & 0.037 & 0.023 & $<0.001$ \\
\hline $\mathrm{NH}_{3}-\mathrm{N}, \mathrm{g} / \mathrm{L}$ & 0.214 & 0.222 & 0.215 & 0.230 & 0.005 & 0.001 & 0.930 & 0.451 & 0.988 & 0.246 \\
\hline Total SCFA ${ }^{\mathrm{d}}, \mathrm{mMol} / \mathrm{L}$ & 183 & 187 & 183 & 177 & 2.28 & $<0.001$ & 0.756 & 0.726 & 0.085 & 0.199 \\
\hline Acetate, $\mathrm{mMol} / \mathrm{L}$ & 121 & 121 & 119 & 117 & 1.47 & $<0.001$ & 0.792 & 0.448 & 0.315 & 0.564 \\
\hline Propionate, $\mathrm{mMol} / \mathrm{L}$ & 35.4 & 40.0 & 37.3 & 34.4 & 0.57 & $<0.001$ & 0.954 & 0.053 & $<0.001$ & 0.012 \\
\hline Butyrate, mMol/L & 18.4 & 17.1 & 17.1 & 16.7 & 0.28 & 0.001 & 0.458 & 0.005 & 0.661 & 0.466 \\
\hline $\mathrm{A}: \mathrm{P}^{\mathrm{e}}$ & 3.45 & 3.08 & 3.25 & 3.45 & 0.02 & $<0.001$ & 0.999 & $<0.001$ & $<0.001$ & 0.002 \\
\hline
\end{tabular}

a Control (CON); soybean oil (SO); soybean grain (SG); calcium salts of fatty acids (CS) (Megalac-E ${ }^{\circledR}$ ).

b Standard error of the mean.

c Probability: D*T I.: diet*time interaction; $\mathrm{C} 1$ = CON vs fat sources (SO. SG. and CS); C2 = SO vs SG and CS; C3 = SG vs CS.

d SCFA: short-chain fatty acids.

e A:P: Acetate to propionate concentrations ratio.

Table 4

Ruminal kinetics in cows of cows fed different fat sources.

\begin{tabular}{|c|c|c|c|c|c|c|c|c|}
\hline \multirow[t]{2}{*}{ Item } & \multicolumn{4}{|l|}{$\operatorname{Diet}^{\mathrm{a}}$} & \multirow[t]{2}{*}{$\mathrm{SEM}^{\mathrm{b}}$} & \multicolumn{3}{|l|}{$P^{\mathrm{c}}$} \\
\hline & $\mathrm{CON}$ & SO & SG & CS & & $\mathrm{C} 1$ & $\mathrm{C} 2$ & $\mathrm{C} 3$ \\
\hline \multicolumn{9}{|l|}{ Digestion rate, $\mathrm{h}^{-1}$} \\
\hline Dry matter & 0.033 & 0.031 & 0.034 & 0.035 & 0.002 & 0.908 & 0.367 & 0.653 \\
\hline $\mathrm{NDF}^{\mathrm{d}}$ & 0.015 & 0.012 & 0.015 & 0.017 & 0.001 & 0.991 & 0.044 & 0.347 \\
\hline \multicolumn{9}{|l|}{ Passage rate, $\mathrm{h}^{-1}$} \\
\hline Dry matter & 0.036 & 0.032 & 0.031 & 0.030 & 0.002 & 0.054 & 0.613 & 0.712 \\
\hline $\mathrm{NDF}^{\mathrm{d}}$ & 0.022 & 0.021 & 0.021 & 0.019 & 0.001 & 0.402 & 0.465 & 0.220 \\
\hline \multicolumn{9}{|c|}{ Ruminal removal rate, $\mathrm{h}^{-1}$} \\
\hline Dry matter & 0.069 & 0.063 & 0.064 & 0.064 & 0.002 & 0.075 & 0.497 & 0.782 \\
\hline $\mathrm{NDF}^{\mathrm{d}}$ & 0.037 & 0.034 & 0.037 & 0.036 & 0.001 & 0.384 & 0.272 & 0.649 \\
\hline $\mathrm{iNDF}^{\mathrm{e}}$ & 0.025 & 0.026 & 0.026 & 0.023 & 0.001 & 0.848 & 0.633 & 0.235 \\
\hline $\operatorname{tdNDF}{ }^{6}$ & 0.049 & 0.044 & 0.048 & 0.052 & 0.003 & 0.877 & 0.335 & 0.604 \\
\hline \multicolumn{9}{|l|}{ Intake, kg/d } \\
\hline $\mathrm{NDF}^{\mathrm{d}}$ & 7.91 & 6.95 & 7.43 & 7.16 & 0.27 & 0.016 & 0.253 & 0.444 \\
\hline $\mathrm{tdNDF}^{6}$ & 5.34 & 4.41 & 5.00 & 4.91 & 0.30 & 0.121 & 0.157 & 0.839 \\
\hline \multicolumn{9}{|l|}{ Ruminal digestibility } \\
\hline $\mathrm{NDF}^{\mathrm{d}}, \mathrm{kg} / \mathrm{d}$ & 3.30 & 2.63 & 3.15 & 3.57 & 0.32 & 0.653 & 0.092 & 0.396 \\
\hline $\mathrm{NDF}^{\mathrm{d}}, \mathrm{kg} / \mathrm{kg}$ & 0.394 & 0.357 & 0.399 & 0.463 & 0.034 & 0.768 & 0.052 & 0.212 \\
\hline $\mathrm{tdNDF}{ }^{6}, \mathrm{~kg} / \mathrm{kg}$ & 0.570 & 0.553 & 0.549 & 0.550 & 0.032 & 0.076 & 0.969 & 0.987 \\
\hline
\end{tabular}

a Control (CON); soybean oil (SO); soybean grain (SG); calcium salts of fatty acids (CS) (Megalac-E ${ }^{\circledR}$ ).

b Standard error of the mean.

c Probability: C1 = CON vs fat sources (SO. SG. and CS); C2 = SO vs SG and CS; C3 = SG vs CS.

d NDF: neutral detergent fiber.

e iNDF: indigestible neutral detergent fiber; tdNDF: truly digestible neutral detergent fiber.

\subsection{Ruminal fermentation}

There was an expected physiological time effect on the ruminal variables evaluated regardless of animal diet. When analyzed independently, fat sources addition increased ruminal $\mathrm{pH}(\mathrm{P}<0.05$; Table 3$)$, decreased rumen concentration of butyrate and acetate to propionate $(\mathrm{A}: \mathrm{P})$ ratio $(\mathrm{P}<0.05)$, and tended to increase ruminal propionate concentration $(\mathrm{P}=0.053)$.

Fat protected sources (SG and $C S$ ) increased $\mathrm{pH}$ and $\mathrm{A}: \mathrm{P}$ ratio $(\mathrm{P}<0.05)$, and decreased ruminal propionate $(\mathrm{P}<0.05)$ when compared to unprotected source (SO). Furthermore, between protected sources, SG increased ruminal propionate concentration and decreased $\mathrm{A}: \mathrm{P}$ ratio and $\mathrm{pH}$, in relation to the $\mathrm{CS}$ diet $(\mathrm{P}<0.05)$. Altogether, our results show that dietary fat sources, especially unprotected ones, affect ruminal fermentation. However, parameters were all within the normal range for animals at this lactation stage.

\subsection{Ruminal kinetics}

Fat source diets had no effects on DM digestion and NDF passage rates. However, fat addition tended to decrease DM passage $(P=0.052$; Table 4$)$ and ruminal removal rates $(P=0.075)$. Animals fed protected sources had higher ruminal NDF digestion rate than those fed SO diet $(\mathrm{P}<0.05)$. 
Table 5

Fatty acid (FA) intake, abomasal flow, and ruminal biohydrogenation rate in cows fed different fat sources.

\begin{tabular}{|c|c|c|c|c|c|c|c|c|}
\hline \multirow[t]{2}{*}{ Item } & \multicolumn{4}{|l|}{ Diet $^{\mathrm{a}}$} & \multirow[t]{2}{*}{ SEM $^{\text {b }}$} & \multicolumn{3}{|l|}{$P^{\mathrm{C}}$} \\
\hline & $\mathrm{CON}$ & SO & SG & $\mathrm{CS}$ & & $\mathrm{C} 1$ & $\mathrm{C} 2$ & $\mathrm{C} 3$ \\
\hline \multicolumn{9}{|l|}{ Intake, $\mathrm{g} / \mathrm{d}$} \\
\hline Total FA & 488 & 857 & 797 & 860 & 60.6 & $<0.001$ & 0.583 & 0.304 \\
\hline $16: 0$ & 55.3 & 99.1 & 98.7 & 97.6 & 7.09 & $<0.001$ & 0.878 & 0.873 \\
\hline $18: 0$ & 15.8 & 27.5 & 26.8 & 27.6 & 1.97 & $<0.001$ & 0.849 & 0.678 \\
\hline cis $18: 1$ & 111 & 192 & 174 & 193 & 13.5 & $<0.001$ & 0.456 & 0.165 \\
\hline $18: 2$ & 246 & 431 & 404 & 431 & 30.5 & $<0.001$ & 0.600 & 0.377 \\
\hline $18: 3$ & 27.2 & 46.5 & 45.4 & 48.4 & 3.38 & $<0.001$ & 0.884 & 0.374 \\
\hline \multicolumn{9}{|c|}{ Abomasal flow, g/d } \\
\hline Total FA & 611 & 984 & 984 & 903 & 118 & $<0.001$ & 0.639 & 0.420 \\
\hline $16: 0$ & 103 & 142 & 172 & 160 & 24.2 & 0.011 & 0.280 & 0.637 \\
\hline $18: 0$ & 438 & 727 & 684 & 610 & 82.5 & $<0.001$ & 0.210 & 0.309 \\
\hline trans $18: 1$ & 13.8 & 44.8 & 11.3 & 33.6 & 5.86 & 0.014 & 0.002 & 0.006 \\
\hline cis $18: 1$ & 19.0 & 22.9 & 58.9 & 38.8 & 16.2 & 0.207 & 0.148 & 0.325 \\
\hline $18: 2$ & 9.0 & 10.5 & 18.1 & 12.8 & 2.22 & 0.045 & 0.049 & 0.064 \\
\hline $18: 3$ & 0.19 & 0.22 & 0.28 & 0.33 & 0.15 & 0.522 & 0.559 & 0.781 \\
\hline \multicolumn{9}{|c|}{ Biohydrogenation rate } \\
\hline $18: 1$ & 0.706 & 0.659 & 0.604 & 0.619 & 0.096 & 0.405 & 0.635 & 0.894 \\
\hline $18: 2$ & 0.962 & 0.975 & 0.955 & 0.968 & 0.006 & 0.530 & 0.039 & 0.091 \\
\hline $18: 3$ & 0.992 & 0.996 & 0.994 & 0.991 & 0.003 & 0.649 & 0.382 & 0.506 \\
\hline
\end{tabular}

a Control (CON); soybean oil (SO); soybean grain (SG); calcium salts of fatty acids (CS) (Megalac- $\left.\mathrm{E}^{\circledR}\right)$.

b Standard error of the mean.

c Probability: C1 = CON vs fat sources (SO. SG. and CS); C2 = SO vs SG and CS; C3 = SG vs CS.

Table 6

Milk production and composition of cows fed different fat sources.

\begin{tabular}{|c|c|c|c|c|c|c|c|c|c|c|}
\hline \multirow[t]{2}{*}{ Item } & \multicolumn{4}{|l|}{ Diet $^{\mathrm{a}}$} & \multirow[t]{2}{*}{ SEM $^{\mathrm{b}}$} & \multicolumn{5}{|l|}{$\mathrm{P}^{\mathrm{c}}$} \\
\hline & $\mathrm{CON}$ & SO & SG & CS & & $\mathrm{C} 1$ & & $\mathrm{C} 2$ & $\mathrm{C} 3$ & \\
\hline \multicolumn{11}{|c|}{ Production, kg/d } \\
\hline Milk & 15.5 & 15 & 14.9 & 15.5 & 0.67 & & 0.570 & 0.538 & & 0.473 \\
\hline $\mathrm{FCM}^{\mathrm{d}}$ & 16.8 & 15.5 & 17.2 & 16.0 & 0.60 & & 0.419 & 0.13 & & 0.153 \\
\hline Fat & 0.62 & 0.55 & 0.66 & 0.56 & 0.02 & & 0.514 & 0.698 & & 0.008 \\
\hline Protein & 0.48 & 0.45 & 0.46 & 0.47 & 0.02 & & 0.348 & 0.91 & & 0.279 \\
\hline Lactose & 0.72 & 0.68 & 0.69 & 0.71 & 0.03 & & 0.297 & 0.799 & & 0.261 \\
\hline \multicolumn{11}{|c|}{ Milk composition, $\mathrm{g} / \mathrm{kg}$} \\
\hline Fat & 40.8 & 38.2 & 46.4 & 37.9 & 0.18 & & 0.987 & 0.174 & & 0.017 \\
\hline Protein & 31.0 & 29.9 & 31.0 & 30.7 & 0.04 & & 0.610 & 0.294 & & 0.734 \\
\hline Lactose & 46.5 & 45.0 & 46.5 & 46.0 & 0.06 & & 0.635 & 0.337 & & 0.755 \\
\hline
\end{tabular}

a Control (CON); soybean oil (SO); soybean grain (SG); calcium salts of fatty acids (CS) (Megalac-E ${ }^{\circledR}$ ).

b Standard error of the mean.

c Probability: C1 = CON vs fat sources (SO, SG, and CS); C2 = SO vs SG and CS; C3 = SG vs CS.

d FCM: Fat corrected milk, estimated according Sklan et al. (1992).

Fat protected sources tended to decrease ruminal NDF digestibility in relation to SO diet $(\mathrm{P}=0.092)$. This effect was replicated when we evaluated NDF digestibility coefficient $(P=0.052)$. In addition, lipid sources tended to decrease ruminal tdNDF digestibility coefficient $(\mathrm{P}=0.076)$ and had no effect on liquid ruminal turnover.

\subsection{Abomasal flow and ruminal biohydrogenation of fatty acids}

Dietary fat sources potentiated the intake of all evaluated fatty acids $(\mathrm{P}<0.05$; Table 5$)$. Similarly, animals fed fat source diets had increased abomasal flows of $\mathrm{C} 18: 2$, trans $\mathrm{C} 18: 1, \mathrm{C} 18: 0, \mathrm{C} 16: 0$, and total fatty acids. Protected lipid sources resulted in higher $\mathrm{C} 18: 2$ abomasal flow and lower trans $\mathrm{C} 18: 1$ flow in relation to $\mathrm{SO}(\mathrm{P}<0.05)$. Between protected fat sources, $\mathrm{SG}$ had lower trans C18:1 abomasal flow, and tended to had higher C18:2 abomasal flow $(\mathrm{P}=0.064)$ than CS.

Dietary treatments had no effect on the biohydrogenation rate of $\mathrm{C} 18: 1$ and $\mathrm{C} 18: 3$. Fat protected sources decreased C18:2 biohydrogenation rate compared to the SO diet. Soybean grain tended to decrease C18:2 biohydrogenation in relation to CS $(\mathrm{P}=0.091)$.

\subsection{Milk yield, composition and fatty acids profile}

Fatty acids addition had no effect on milk yield and composition ( $P>0.05$; Table 6 ). However, animals fed with CS showed lower milk fat yield and concentration when compared with those fed SG $(\mathrm{P}<0.05)$. 
Table 7

Milk fatty acid (FA) profile of dairy cows fed different fat sources.

\begin{tabular}{|c|c|c|c|c|c|c|c|c|}
\hline \multirow[t]{2}{*}{ Item } & \multicolumn{4}{|l|}{ Diet $^{\mathrm{a}}$} & \multirow[t]{2}{*}{ SEM $^{\mathrm{b}}$} & \multicolumn{3}{|l|}{$P^{c}$} \\
\hline & $\mathrm{CON}$ & SO & SG & CS & & $\mathrm{C} 1$ & $\mathrm{C} 2$ & $\mathrm{C} 3$ \\
\hline \multicolumn{9}{|l|}{$\mathrm{FA}, \mathrm{g} / \mathrm{kg}$ total FA } \\
\hline $\mathrm{C} 4: 0$ & 11.0 & 7.0 & 7.1 & 12.1 & 1.84 & 0.203 & 0.170 & 0.027 \\
\hline C6:0 & 13.4 & 7.2 & 9.1 & 10.4 & 1.82 & 0.023 & 0.210 & 0.575 \\
\hline C8:0 & 10.0 & 6.1 & 7.7 & 6.5 & 1.07 & 0.005 & 0.373 & 0.365 \\
\hline C10:0 & 25.6 & 19.3 & 21.1 & 15.3 & 1.91 & 0.003 & 0.619 & 0.033 \\
\hline $\mathrm{C} 11: 0$ & 2.4 & 1.5 & 1.6 & 0.8 & 0.25 & $<0.001$ & 0.415 & 0.041 \\
\hline C12:0 & 33.9 & 25.7 & 26.5 & 20.7 & 2.22 & $<0.001$ & 0.420 & 0.055 \\
\hline $\mathrm{C} 14: 0$ & 121 & 98 & 100 & 89 & 4.50 & $<0.001$ & 0.563 & 0.122 \\
\hline C14:1 & 5.4 & 4.5 & 4.5 & 4.2 & 0.53 & $<0.001$ & 0.736 & 0.523 \\
\hline C15:0 & 3.3 & 2.4 & 1.9 & 1.6 & 0.40 & $<0.001$ & 0.077 & 0.440 \\
\hline C16:0 & 351 & 306 & 307 & 301 & 11.1 & $<0.001$ & 0.892 & 0.717 \\
\hline $\mathrm{C} 16: 1 \mathrm{cis}$ & 14.5 & 12.5 & 10.8 & 11.0 & 1.36 & 0.014 & 0.206 & 0.849 \\
\hline C17:0 & 2.1 & 1.9 & 2.1 & 1.9 & 0.36 & 0.616 & 0.795 & 0.458 \\
\hline C18:0 & 116 & 158 & 176 & 160 & 12.3 & $<0.001$ & 0.360 & 0.205 \\
\hline C18: 1 trans 11 & 12.2 & 21.2 & 6.0 & 21.1 & 3.64 & 0.281 & 0.057 & 0.002 \\
\hline C18:1cis 9 & 277 & 317 & 302 & 322 & 17.1 & 0.024 & 0.762 & 0.293 \\
\hline C18:2 n-6. cis & 20.6 & 17.7 & 29.4 & 23.2 & 2.76 & 0.148 & $<0.001$ & 0.015 \\
\hline C18:3 & 1.0 & 1.2 & 1.5 & 1.1 & 0.25 & 0.297 & 0.541 & 0.213 \\
\hline C20:0 & 1.1 & 1.4 & 1.5 & 1.2 & 0.12 & 0.023 & 0.414 & 0.026 \\
\hline cis-9.trans-11 CLA & 5.0 & 8.8 & 1.7 & 7.5 & 1.94 & 0.598 & 0.046 & 0.020 \\
\hline$<\mathrm{C} 16$ & 228 & 173 & 181 & 162 & 11.4 & $<0.001$ & 0.903 & 0.256 \\
\hline C16 & 351 & 306 & 307 & 301 & 11.1 & 0.001 & 0.892 & 0.717 \\
\hline$>\mathrm{C} 16$ & 450 & 541 & 532 & 552 & 25.1 & 0.003 & 0.982 & 0.548 \\
\hline Unsaturated C18 & 310 & 356 & 338 & 369 & 20.3 & 0.022 & 0.890 & 0.164 \\
\hline Saturated C18 & 116 & 158 & 176 & 160 & 12.3 & $<0.001$ & 0.360 & 0.205 \\
\hline Saturated & 693 & 636 & 663 & 622 & 17.4 & 0.004 & 0.715 & 0.068 \\
\hline Unsaturated & 336 & 384 & 356 & 393 & 22.0 & 0.035 & 0.628 & 0.117 \\
\hline $\mathrm{U}: \mathrm{S}$ FA ratio ${ }^{\mathrm{d}}$ & 2.15 & 1.73 & 1.88 & 1.60 & 0.15 & 0.006 & 0.917 & 0.109 \\
\hline
\end{tabular}

a Control (CON); soybean oil (SO); soybean grain (SG); calcium salts of fatty acids (CS) (Megalac-E ${ }^{\circledR}$ ).

b Standard error of the mean.

c Probability: $\mathrm{C} 1$ = CON vs fat sources (SO. SG. and CS); C2 = SO vs SG and CS; C3 = SG vs CS

d Unsaturated to saturated fatty acids ratio.

Animals fed with fat source diets had lower milk concentration of short chain fatty acids, including C6:0, C8:0, C10:0, C11:0, C12:0, C14:0, C14:1, C15:0, C16:0 and C16:1 FA in relation to animals fed CON diet ( $<<0.05$; Table 7). Soybean grain increased $\mathrm{C10}: 0, \mathrm{C} 11: 0$ e $\mathrm{C12:0}$ milk concentration in relation to $\mathrm{SC}(\mathrm{P}<0.05)$. In addition, cows fed diets with lipid sources had higher milk concentration of $\mathrm{C} 18: 0, \mathrm{C} 20: 0$, cis9 $\mathrm{C} 18: 1$, and total saturated and unsaturated C18 FA than those fed CON $(\mathrm{P}<0.05)$

Dietary fat addition increased milk unsaturated FA concentration $(\mathrm{P}<0.05)$. Animals fed with protected fat source diets had higher milk C18:2 $n-6$, and lower cis 9 trans 11 CLA concentrations compared those fed SO $(\mathrm{P}<0.05)$. Soybean grain decreased C18:2 $n-6$ and increased trans11 C18:1 and cis9 trans11 CLA milk concentrations than CS $(\mathrm{P}<0.05)$.

\subsection{Energy and nitrogen balances and microbial protein synthesis}

Diets had no effect on nitrogen balance, nitrogen utilization efficiency, microbial protein synthesis, and microbial growth efficiency $(\mathrm{P}>0.05$; Table 8$)$.

\section{Discussion}

The absorption of FAs in the duodenum of dairy cows affects animal health, performance, and ultimately product quality. We evaluated how different fat sources affect ruminal kinetics and FA flow, and found that oilseed results in lower ruminal biohydrogenation rate and increased abomasal flow of unsaturated FAs, when compared to vegetable oil and unsaturated FA calcium salts.

In the current study, fat-supplemented diets decreased dry matter intake (DMI) in relation to the control diet. Several authors have reported this effect of dietary fat addition (Palmquist and Jenkins, 1980; Casper et al., 1990; Schauff et al., 1992). The mechanisms underlying fat-induced reduction in DMI have yet to be fully established but may result from the acceptability of high fat content diets, release of gut hormones, and fat oxidation in the liver (Allen, 2000). Alternatively, gut motility associated with increased cholecystokinin (CCK) and slow gastric emptying may also contribute to the reduction in DMI (Liddle et al., 1985). We speculate based on our results that this effect may also reflect the distinct energy density of fat-containing diets (Table 1). Because we formulated diets to have similar CP and NDF levels, fat supplementation also reduced the intake of these nutrients. 
Table 8

Nitrogen and energy balances, and microbial protein synthesis in cows fed different fat sources.

\begin{tabular}{|c|c|c|c|c|c|c|c|c|}
\hline \multirow[t]{2}{*}{ Item } & \multicolumn{4}{|l|}{ Diet $^{\mathrm{a}}$} & \multirow[t]{2}{*}{ SEM $^{\text {b }}$} & \multicolumn{3}{|l|}{$P^{c}$} \\
\hline & $\mathrm{CON}$ & SO & SG & $\mathrm{CS}$ & & $\mathrm{C} 1$ & $\mathrm{C} 2$ & $\mathrm{C} 3$ \\
\hline $\mathrm{N}$ intake, $\mathrm{g} / \mathrm{d}$ & 442 & 393 & 390 & 407 & 15.4 & 0.019 & 0.601 & 0.532 \\
\hline $\mathrm{N}$ balance, $\mathrm{g} / \mathrm{d}$ & 206 & 159 & 168 & 198 & 14.8 & 0.146 & 0.653 & 0.136 \\
\hline $\mathrm{N}$ efficiency ${ }^{\mathrm{d}}$ & 0.167 & 0.173 & 0.191 & 0.181 & 0.007 & 0.236 & 0.303 & 0.601 \\
\hline $\mathrm{NE}_{\mathrm{L}}^{\mathrm{e}} / \mathrm{DEI}^{\mathrm{f}}$ & 0.282 & 0.295 & 0.284 & 0.293 & 0.012 & 0.847 & 0.785 & 0.813 \\
\hline Energy balance, $\mathrm{MJ} / \mathrm{d}$ & 48.5 & 36.3 & 44.6 & 35.8 & 7.11 & 0.458 & 0.678 & 0.563 \\
\hline $\mathrm{CPmic}^{\mathrm{g}}, \mathrm{g} / \mathrm{d}$ & 1032 & 1128 & 1019 & 1020 & 24.0 & 0.961 & 0.245 & 0.765 \\
\hline Microbial efficiency ${ }^{\mathrm{h}}, \mathrm{g} / \mathrm{kg}$ & 64.5 & 76.7 & 67.9 & 68.4 & 1.79 & 0.507 & 0.174 & 0.897 \\
\hline
\end{tabular}

a Control (CON); soybean oil (SO); soybean grain (SG); calcium salts of fatty acids (CS) (Megalac-E ${ }^{\circledR}$ ).

b Standard error of the mean.

c Probability: $\mathrm{C} 1$ = CON vs fat sources (SO. SG. and CS); C2 = SO vs SG and CS; C3 = SG vs CS.

d $\mathrm{N}$ efficiency: $\mathrm{N}$ milk to $\mathrm{N}$ intake ratio.

e NEL: Net energy for lactation.

f DEI: Digestible energy intake.

g CPmic: Microbial crude protein.

h Microbial efficiency: $g$ de microbial crude protein to $\mathrm{kg}$ of TDN intake.

The three fat-supplemented diets decreased DMI without altering total weight of rumen content. Thus, dietary fat decreased DM passage rate and ruminal removal rate. Digestion and passage rates oppose each other in that a slower passage rate correlates with higher digestion (Allen and Mertens, 1988). Therefore, we would expect that the decrease in passage rate caused by dietary fat should result in improved digestion. However, we observed that supplemental fat tended to decrease the tdNDF ruminal digestion (relative value). This difference resulted from the inhibitory effects of the free fat in the SO diet on rumen fermentation that pulled down the average NDF digestibility of fat-containing diets as a group. The inhibitory effects of free fat on ruminal NDF digestibility has been previously reported (AbuGhazaleh et al., 2004).

An increase in rumen propionate concentration and decrease in A:P ratio was observed in animals fed fat-rich diets. The effect on rumen SCFA concentration may result of cellulolytic bacteria growth inhibition (Yang et al., 2009) promoting amylolytic bacteria growth (Patra and Yu, 2013) which favor propionate production.

Animals fed fat-supplemented diets had increased ruminal $\mathrm{pH}$ when compared to control. This difference mostly results from a pH increase induced by the CS diet, which raised the average for the combined fat-supplemented diets. This effect of FA calcium salt diets has not been described previously and the mechanisms underlying it remain unknown. Rumen pH of animals fed CS was 0.31 greater than that of SG-fed animals. Lower ruminal pH can change the microbial population, altering usual ruminal biohydrogenation routes by changing the formation of cis 9 trans $11 \mathrm{C} 18: 2$ and trans $11 \mathrm{C} 18: 1$ by trans 10 cis 12 C18:2 and trans10 C18:1 formation, key intermediates of linoleic acid biohydrogenation (Griinari et al., 1998; Bauman and Griinari, 2003; Shingfield et al., 2010). In the present study, even with lower rumen pH in SG-fed animals, biohydrogenation rates were lower in comparison with CS-fed animals.

Fat-supplemented diets increased abomasal flow of all evaluated FAs, except for cis-C18:1 and C18:3. Diets containing low concentrations of these unsaturated FAs are also more subjected to the biohydrogenation process (Harvatine and Allen, 2006). Protected FA sources decreased C18:2 biohydrogenation, with a consequent increase in its abomasal flow. Protected fat sources decreased trans C18:1 flow, a known intermediate product of C18:2 biohydrogenation (Mosley et al., 2002). When compared to the CS diet, the SG diet decreased biohydrogenation and increased the flow of C18:2 while reduces trans C18:1 abomasal flow (Table 5). This result shows that an oilseed diet (SG) provides greater FA protection than calcium salts. The digestion of commercially available FA calcium salts should begin in the low pH environment of the abomasum. However, the $5.6 \mathrm{pKa}$ of soybean calcium salts lies below the lower limits of rumen $\mathrm{pH}$ (Sukhija and Palmquist, 1990). Thus, the desired protective effect against ruminal biohydrogenation does not occur at the advertised rate.

Milk short-chain fatty acids are mainly synthesized in the epithelial cells of the mammary gland, from acetate and $\beta$ hidroxibutirate, which are originated in the rumen. In this study, milk short chain FA profile results suggests inhibition of short chain FA synthesis of milk fat in cows fed with fat sources which can be explained by reduced ruminal acetate to propionate ratio, and, the fatty acids supply for the mammary gland (Bauman and Griinari, 2003).

An assessment of the inclusion and fat digestion processes in ruminants shows that most fatty acids are changed by ruminal metabolism, so biohydrogenation is generally not complete, resulting in a wide variety of fatty acids (Byers and Schehing, 1993). So when an incomplete biohydrogenation of PUFA occurs, there is an increase in duodenal flow of fatty acids C18: 1 trans and conjugated linoleic acids CLA cis-9,-11and trans-11and CLA trans-10, cis-12, the latter of which presents an attested inhibiting effect over milk fat synthesis (Bauman and Griinari, 2001). As observed in this study, fat sources diets changed milk fatty acids profile and animals fed SG diets had higher concentration of FA C18:2 on milk and in the abomasum, and lower concentration of intermediaries the biohydrogenation (C18:1 trans; CLA cis-9,-11 trans-11 and CLA trans-10, cis-12) than animals fed CS diet.

The protection of whole raw soybean grain FA against ruminal bio-hydrogenation, improves abomasal C18:2 concentration and decreases isomer formation, which are associated with milk fat depression. This result demonstrates the power of protection and the slow liberation of soybean grain lipids. 


\section{Conclusion}

The natural physical barriers of the oilseed more efficiently protected FAs against ruminal biohydrogenation than the chemical barrier provided by calcium salts. This finding may guide the development of new rumen inert products. Alternatively, future studies should evaluate the FA content and flow of other oilseeds that might have greater technical and economic viability than commercial products.

\section{Conflict of interests}

The authors declare that are no conflicts of interest to the current manuscript.

\section{Acknowledgements}

The authors thank the University of São Paulo and Dairy Cattle Research Laboratory for providing the physical infrastructure and staff necessary for this study. We are also grateful for scholarship support to Rafael Villela Barletta (FAPESP - grant \#2011/09265-1) and financial support (FAPESP \#2010/00690-9).

\section{References}

AOAC, 2000. Official Methods of Analysis of AOAC International, 17th edition. AOAC International, Gaithersburg, MD, USA.

AbuGhazaleh, A.A., Schingoethe, D.J., Hippen, A.R., Kalscheur, K.F., 2004. Conjugated linoleic acid increases in milk when cows fed fish meal and extruded soybeans for an extended period of time. J. Dairy Sci. 87, 1758-1766.

Allen, M.S., Mertens, D.R., 1988. Evaluating constraints on fiber digestion by rumen microbes. J. Nutr. 118, 261-270

Allen, M.S., 2000. Effects of diet on short-term regulation of feed intake by lactating dairy cattle. J. Dairy Sci. 83, 1598-1624.

Bauman, D.E., Griinari, J.M., 2001. Regulation and nutritional manipulation of milk fat: low fat milk syndrome. Livest. Prod. Sci. 70, 15-29.

Bauman, D.E., Griinari, J.M., 2003. Nutritional regulation of milk fat synthesis. Annu. Rev. Nutr. 2 (23), $203-227$.

Beam, T.M., Jenkins, T.C., Moate, P.J., Kohn, R.A., Palmquist, D.L., 2000. Effects of amount and source of fat on the rates of lipolysis and biohydrogenation of fatty acids in ruminal contents. J. Dairy Sci. 83, 2564-2573.

Broderick, G.A., Kang, J.H., 1980. Automated simultaneous determination of ammonia and total amino-acids in ruminal fluid and in vitro media. J. Dairy Sci. 63, 64-75.

Byers, F.M., Schehing, G.T., 1993. Los lipidos en la nutricion de los rumiantes, In: Church, D.C., (Editor), El rumiante fisiología digestive e nutricion. Zaragoza: Acribia, pp. 339-356.

Casali, A.O., Detmann, E., Valadares Filho, S.C., Pereira, J.C., Henriques, L.T., Freitas, S.G., Paulino, M.F., 2008. Influence of incubation time and particles size on indigestible compounds contents in cattle feeds and feces obtained by in situ procedures. Braz. J. Anim. Sci. 37, 335-342.

Casper, D.P., Schingoethe, D.J., Eisenbeisz, W.A., 1990. Response of early lactation cows to diets that vary in ruminal degradability of carbohydrates and amount of fat. J. Dairy Sci. 73, 425-444.

Chen, X.B., Gomes, M.J., 1992. Estimation of microbial protein supply to sheep and cattle based on urinary excretion of purine derivatives-an overview of the technical details. Ocasional publication 1992, International Feed Resources Unit, Rowett Research Institute, Aberdeen, UK., p. 22.

Chilliard, Y., Ferlay, A., Faulconnier, Y., Bonnet, M., Rouel, J., Bocquier, F., 2000. Adipose tissue metabolism and its role in adaptations to undernutrition in ruminants. Proc. Nutr. Soc. 59, 127-134.

Chizzotti, M.L., Valadares Filho, S.C., Valadares, R.F.D., Chizzotti, F.H.M., Tedeschi, L.O., 2008. Determination of creatinine excretion and evaluation of spot urine sampling in Holstein cattle. Livest. Prod. Sci. 113, 218-225.

Eastridge, M.L., Firkins, J.L., 1991. Feeding hydrogenated fatty-acids and triglycerides to lactating dairy-cows. J. Dairy Sci. $74,2610-2616$.

Faichney, G.J., 1975. The use of markers to partition digestion within the gastro-intestinal tract of ruminants. In: McDonald, I.W., Warner, A.C.I. (Eds.), Digestion and Metabolism in the Ruminant. University of New England Publishing Unit, Armidale, NSW, Australia, pp. $227-291$.

Feng, S., Lock, A.L., Garnsworthy, P.C., 2004. Technical note: a rapid lipid separation method for determining fatty acid composition of milk. J. Dairy Sci. 87, 3785-3788.

Folch, J., Lees, M., Stanley, G.H.S., 1957. A simple method for the isolation and purification of total lipides from animal tissues. J. Biol. Chem. 226, 497-509.

Fujihara, S., Yamaguchi, M., 1978. Effects of allopurinol 4-hydroxypyrazolo(3,4-d) pyrimidine on metabolism of allantoin in soybean plants. Plant Physiol. $62,134-138$.

Griinari, J.M., Dwyer, D.A., McGuire, M.A., Bauman, D.E., Palmquist, D.L., Nurmela, K.V.V., 1998. Trans-octadecenoic acids and milk fat depression in lactating dairy cows. J. Dairy Sci. $81,1251-1261$

Harvatine, K.J., Allen, M.S., 2006. Effects of fatty acid supplements on ruminal and total tract nutrient digestion in lactating dairy cows. J. Dairy Sci. 89, $1092-1103$

Hyden, S., 1955. A turbidimetric method for the determination of higher polyethylene glycols in biological materials. K. Lantbrukshoegsk. Ann. 22, $139-145$.

Jenkins, T.C., Bridges Jr., W.C., 2007. Protection of fatty acids against ruminal biohydrogenation in cattle. Eur. J. Lipid Sci. Technol. $109,778-789$.

Jenkins, T.C., Wallace, R.J., Moate, P.J., Mosley, E.E., 2008. Board-invited review: recent advances in biohydrogenation of unsaturated fatty acids within the rumen microbial ecosystem. J. Anim. Sci. 86, 397-412

Kenward, M., Roger, J., 1997. Small sample inference for fixed effects from restricted maximum likelihood. Biometrics $53,983-997$.

Kramer, J.K.G., Fellner, V., Dugan, M.E.R., Sauer, F.D., Mossoba, M.M., Yurawecz, M.P., 1997. Evaluating acid and base catalysts in the methylation of milk and rumen FA with special emphasis on conjugated dienes and total trans fatty acids. Lipids 32, 1219-1228.

Liddle, R.A., Goldfine, I.D., Rosen, M.S., Taplitz, R.A., Williams, J.A., 1985. Cholecystokinin bioactivity in human-plasma - molecular-forms, responses to feeding, and relationship to gallbladder contraction. J Clin. Invest. 75, 1144-1152.

Mansbridge, R.J., Blake, J.S., 1997. Nutritional factors affecting the fatty acid composition of bovine milk. Br. J. Nutr. 78, $37-47$.

Mosley, E.E., Powell, G.L., Riley, M.B., Jenkins, T.C., 2002. Microbial biohydrogenation of oleic acid to trans isomers in vitro. J. Lipid Res. $43,290-296$.

National Research Council (NRC), 2001. Nutrient Requirements of Dairy Cattle, 7th revised edition. National Academy Press, Washington, DC, USA, pp. 381

Onetti, S.G., Grummer, R.R., 2004. Response of lactating cows to three supplemental fat sources as affected by forage in the diet and, stage of lactation: a meta-analysis of literature. Anim. Feed Sci. Technol. 105, 65-82.

Palmquist, D.L., Jenkins, T.C., 1980. Fat in lactation rations-review. J. Dairy Sci. 63, 1-14.

Patra, A.K., Yu, Z., 2013. Effects of coconut and fish oils on ruminal methanogenesis, fermentation, and abundance and diversity of microbial populations in vitro. J. Dairy Sci. 96, 1782-1792.

Schauff, D.J., Clark, J.H., Drackley, J.K., 1992. Effects of feeding lactating dairy-cows diets containing extruded soybeans and calcium salts of long-chain fatty-acids. J. Dairy Sci. 75, 3003-3019. 
Shen, Z.M., Seyfert, H.M., Lohrke, B., Schneider, F., Zitnan, R., Chudy, A., Kuhla, S., Hammon, H.M., Blum, J.W., Martens, H., Hagemeister, H., Voigt, J., 2004. An energy-rich diet causes rumen papillae proliferation associated with more IGF type 1 receptors and increased plasma IGF-1 concentrations in young goats. J. Nutr. 134, 11-17.

Shingfield, K.J., Bernard, L., Leroux, C., Chilliard, Y., 2010. Role of trans fatty acids in the nutritional regulation of mammary lipogenesis in ruminants. Animal 4, 1140-1166.

Silvestre, F.T., Carvalho, T.S.M., Crawford, P.C., Santos, J.E.P., Staples, C.R., Jenkins, T., Thatcher, W.W., 2011. Effects of differential supplementation of fatty acids during the peripartum and breeding periods of Holstein cows: II. Neutrophil fatty acids and function, and acute phase proteins. J. Dairy Sci. 94, 2285-2301.

Sklan, D., Ashkenazi, R., Brun, A., Devorin, A., Tabori, K., 1992. Fatty acids, calcium soaps and cottonseeds fed to high yielding cows. J. Dairy Sci. 75, 2463-2472.

Sukhija, P.S., Palmquist, D.L., 1990. Dissociation of calcium soaps of long-chain fatty-acids in rumen fluid. J. Dairy Sci. $73,1784-1787$.

VanNevel, C.J., Demeyer, D.I., 1996. Influence of pH on lipolysis and biohydrogenation of soybean oil by rumen contents in vitro. Reprod. Nutr. Dev. 36 53-63.

VanSoest, P.J., Robertson, J.B., Lewis, B.A., 1991. Methods for dietary fiber, neutral detergent fiber, and nonstarch polysaccharides in relation to animal nutrition. J. Dairy Sci. 74, 3583-3597.

Waldo, D.R., Smith, L.W., Cox, E.L., 1972. Model of cellulose disappearance from the rumen. J. Dairy Sci. 55, 125-129.

Williams, C.H., David, D.J., Iisma, O., 1962. The determination of chromic oxide in feces samples by atomic absorption spectrophotometry. J. Agric. Sci. 59, $381-385$.

Yang, S.L., Bu, D.P., Wang, J.Q., Hu, Z.Y., Li, D., Wei, H.Y., Zhou, L.Y., Loor, J.J., 2009. Soybean oil and linseed oil supplementation affect profiles of ruminal microorganisms in dairy cows. Animal 3, 1562-1569. 